\title{
Pathology, isolation and molecular characterisation of a ranavirus from the common midwife toad Alytes obstetricans on the Iberian Peninsula
}

\author{
Ana Balseiro" ${ }^{1, *}$, Kevin P. Dalton ${ }^{2}$, Ana del Cerro ${ }^{1}$, Isabel Marquez ${ }^{1}$, \\ Andrew A. Cunningham ${ }^{3}$, Francisco Parra ${ }^{2}$, José M. Prieto ${ }^{1}$, R. Casais ${ }^{1}$ \\ ${ }^{1}$ SERIDA, Servicio Regional de Investigación y Desarrollo Agroalimentario, Laboratorio de Sanidad Animal, \\ 33299 Jove, Gijón, Spain \\ ${ }^{2}$ Departamento de Bioquímica y Biología Molecular, Instituto Universitario de Biotecnología de Asturias, \\ Universidad de Oviedo, 33006 Oviedo, Spain \\ ${ }^{3}$ Institute of Zoology, Regent's Park, London NW1 4RY, UK
}

\begin{abstract}
We describe the pathology, isolation and characterisation of a virus responsible for an outbreak of a systemic haemorrhagic disease causing high mortality in tadpoles of the common midwife toad Alytes obstetricans in the 'Picos de Europa' National Park in northern Spain. The virus, provisionally designated as the common midwife toad virus (CMTV), was isolated from homogenates of visceral tissue from diseased toad tadpoles following inoculation on epithelioma papulosum cyprini (EPC) cells. Molecular characterisation of the virus, including sequence analysis of the DNA polymerase and major capsid protein genes, showed that the isolated virus was a ranavirus with marked sequence identity to other members of the genus Ranavirus. A rabbit antiserum raised against purified virions was prepared and used to definitively demonstrate systemic distribution of the virus in diseased tadpoles, indicating that the isolated virus was the primary pathogen.
\end{abstract}

KEY WORDS: Common midwife toad · Alytes obstetricans · Ranavirus $\cdot$ Pathology $\cdot$ Virology Immunohistochemistry

\section{INTRODUCTION}

Iridoviruses encompass 5 genera: Iridovirus, Chloriridovirus, Ranavirus, Megalocytivirus and Lymphocystivirus (Chinchar et al. 2005). Of these, the genus Ranavirus contains pathogens of fish, amphibians, and reptiles (Langdon et al. 1986, Hyatt et al. 2002, Cunningham et al. 2008). Frog virus 3 (FV3) is the type species of the genus Ranavirus and the bestcharacterised member of the family Iridoviridae (Van Regenmortel et al. 2000). FV3 and closely related ranaviruses (e.g. RUK in the UK; Hyatt et al. 2000) have been implicated as a cause of mass amphibian deaths worldwide (Hyatt et al. 2000). In addition to FV3, other important pathogenic ranaviruses are the tiger frog virus (TFV) (Weng et al. 2002) and Ambystoma tigrinum stebbensi virus (ATV) (Jan- covich et al. 1997, Bollinger et al. 1999). Ranaviruses have been identified as the cause of explosive disease outbreaks, with high mortality rates due to systemic disease in frogs in the US (Majji et al. 2006), Australia (Speare \& Smith 1992), Croatia (Fijan et al. 1991) and the UK (Cunningham et al. 1996, 2007), and in salamanders in the US (Jancovich et al. 1997, Docherty et al. 2003) and Canada (Bollinger et al. 1999). In most disease outbreaks, death is due to systemic haemorrhaging and tissue necrosis. However, infection with RUK in the UK may present 2 main disease syndromes: a peracute disease characterised by systemic haemorrhages and a chronic disease characterised by skin ulceration with no internal gross lesions (Cunningham et al. 1996, 2007). In both presentations, however, systemic infection with ranavirus can be demonstrated (Cunningham et al. 2008). 
In this report, we describe the isolation and characterisation of a ranavirus responsible for a systemic haemorrhagic disease in tadpoles of the common midwife toad Alytes obstetricans (CMT) that caused a high mortality rate in the 'Picos de Europa' National Park. Based on the species infected, disease characteristics, and taking into account that the agent could be filtered and propagated on epithelioma papulosum cyprini (EPC) cells, we suspected a ranavirus as the causative agent. The lesions observed were similar to those described for ranavirus disease in frogs and other amphibians (Cunningham et al. 1996). Macroscopic lesions consisted of systemic haemorrhages. Microscopically, round, intracytoplasmic, basophilic inclusions were observed in the skin, liver, kidney and gastrointestinal tract, accompanied by varying degrees of necrosis. Specific immunolabelling to the virus was observed in these organs. Sequence analysis of the virus DNA polymerase and the major capsid protein (MCP) genes showed that the virus isolated, provisionally designated as the common midwife toad virus (CMTV), had a marked sequence identity to epizootic haematopoietic necrosis virus (EHNV), FV3, TFV, ATV and other members of the genus Ranavirus in the Family Iridoviridae. This represents the first evidence of ranavirus infection causing high mortality in the CMT and is also the first described isolation of a ranavirus on the Iberian Peninsula.

\section{MATERIALS AND METHODS}

On 7 September 2007, a large number of CMT tadpoles and a newt larva (Triturus alpestris) were found dead in an isolated, permanent water trough in the Picos de Europa National Park (northern Spain; $\left.43^{\circ} 19^{\prime} \mathrm{N}, 4^{\circ} 45^{\prime} \mathrm{W}\right)$. A sample of 9 live tadpoles and the dead newt were taken to the SERIDA veterinary laboratory in Gijón (Asturias), where the animals were necropsied. Of the 9 tadpoles, 6 showed clinical signs (macroscopic haemorrhages; protruding gills in 1 tadpole). The dead newt showed similar haemorrhages. Diseased tadpoles were not observed in any of the similar troughs in the area, the closest one being $\sim 1 \mathrm{~km}$ away. The tadpoles were euthanized with an overdose of the anaesthetic 2-phenoxi-ethanol (Panreac) and examined immediately after death. Tissue samples were taken for bacteriological, virological, and histopathological (including immunohistochemical) studies. No studies were done with the newt larva because it was too decomposed for useful examination.

Bacteriological studies. For the bacteriological analyses, internal organs were plated immediately after death onto Triptone soya agar (TSA, OXOID) and blood agar culture media. Liver and heart were analysed from 2 large tadpoles; the remaining tadpoles proved too small for analysis of separate organs, so the whole internal content of each tadpole that contained all organs was analysed. Samples were incubated at 22 or $37^{\circ} \mathrm{C}$ for $24 \mathrm{~h}$, after which any bacterial colonies present were identified using colony morphology, Gram's stain and the API 20 E biochemical strip system (APIbioMérieux).

Cell culture. A fish cell line (EPC cells; Fijan et al. 1983) was obtained from the Danish Institute for Food and Veterinary Research and used to isolate and propagate the virus. Cells were grown in T25 flasks at $15^{\circ} \mathrm{C}$ in HEPES-buffered modified Eagle's MEM (HEPESMEM, Sigma-Aldrich), which contained $25 \mathrm{mM}$ HEPES, fetal bovine serum $(10 \%)$, and antibiotics (penicillin G $\left[\begin{array}{lll}100 & \mathrm{IU} & \mathrm{ml}^{-1}\end{array}\right]$, dihydrostreptomycin [100 $\left.\mu \mathrm{g} \mathrm{ml}^{-1}\right]$ and amphotericin B [2.5 $\left.\mu \mathrm{g} \mathrm{ml}^{-1}\right]$ ).

Virological studies. Visceral tissues from tadpoles were weighed and homogenised in 10 volumes of HEPES-MEM using a stomacher. The resulting tissue homogenates were clarified by centrifugation (20 min at $1000 \times g$ and $4^{\circ} \mathrm{C}$ in a Beckman Allegra X-22R centrifuge) and the supernatant was filtered through a $0.45 \mu \mathrm{m}$ filter. One $\mathrm{ml}$ of the filtrate was inoculated onto EPC cell cultures, which were then incubated for $1 \mathrm{~h}$ at $15^{\circ} \mathrm{C}$ with occasional rocking. Afterwards, $5 \mathrm{ml}$ of HEPES-MEM were added. The EPC cells, maintained at $15^{\circ} \mathrm{C}$ in HEPES-MEM, were observed for cytopathic effects (CPE) at regular intervals. Once the cell monolayer was completely destroyed, cells and medium were freeze-thawed three times and the mixture was clarified by centrifugation for $10 \mathrm{~min}$ at $1000 \times$ $g$ and $4^{\circ} \mathrm{C}$, to eliminate remaining cells and cell nuclei. Clarified cell lysate was stored at $-80^{\circ} \mathrm{C}$ and used as a virus stock for virus passage and characterisation. Mock-infected EPC monolayers were concurrently processed to use as a control for CPE.

Analysis of virus DNA: EPC cells incubated with tadpole extracts were grown in T25 flasks until 100\% CPE was observed. The cultures were then harvested, the cell pellets suspended in $100 \mathrm{mM}$ Tris- $\mathrm{HCl}$ ( $\mathrm{pH}$ 7.5)$5 \mathrm{mM}$ EDTA-0.2\% sodium dodecyl sulphate-200 mM $\mathrm{NaCl}$ containing $0.1 \mathrm{mg} \mathrm{ml}^{-1}$ proteinase $\mathrm{K}(400 \mu \mathrm{l})$, incubated at $50^{\circ} \mathrm{C}$ for $2 \mathrm{~h}$, and extracted with phenolchloroform followed by chloroform. Nucleic acids were ethanol precipitated and resuspended in $40 \mu$ l of water (Sigma-Aldrich). The resulting solution was analysed for the presence of a DNA fragment corresponding to the viral DNA polymerase gene using the PCR reaction conditions described by Hanson et al. (2006), with degenerate upstream (5'-cgg aat tct aGA YTT YGC NWS NYT NTA YCC-3') and downstream (5'-CCC gaa ttc aga tcT CNG TRT CNC CRT A-3') oligonucleotide primers. The viral DNA extracted from EPC-infected cells was also analysed for the presence of a highly conserved re- 
gion in the amino terminal of the MCP of FV3 and other iridoviruses using the PCR reaction conditions described by Mao et al. (1997), with 5'-GAC TTG GCC ACT TAT GAC-3' (aa 15-20 within the FV3 MCP) as forward primer and 5'-GTC TCT GGA GAA GAA GAA-3' (aa 186-191 within the FV3 MCP) as reverse primer. The resulting DNA products were gel purified and both strands were sequenced using the ABI prism BigDye terminator kit version 3.1 (Applied Biosystems) and the 3100 genetic analyser (Applied Biosystems). The nucleotide sequence was used to do a BLAST (basic local alignment search tool; Altschul et al. 1997) search for homologous sequences in GenBank. The CMTV sequences were submitted to the EMBL data base: the DNA polymerase gene accession number is FM165473, while the protein identification number is CAQ63494.1; the MCP gene accession number is FM213466 and the protein identification number is CAR82589.1. To determine the relationship of the newly isolated virus with other iridoviruses, multiple alignment of several sequences was performed using the programs Clustal X (1.81) (Thompson et al. 1997) and Genedoc (Karreman 2002). Phylogenetic and molecular evolutionary analyses were conducted using MEGA version 4 (Tamura et al. 2007).

Virus purification: EPC cells were grown to confluent monolayers, infected with supernatants from a previous culture (passage 2) and incubated at $15^{\circ} \mathrm{C}$ until CPE was $100 \%$. The cultures were then subjected to 3 freeze-thawing cycles, sonicated for $4 \mathrm{~min}$ in an ultrasonic water bath and centrifuged for $10 \mathrm{~min}$ at $1000 \times \mathrm{g}$ and $4^{\circ} \mathrm{C}$. Virus particles were pelleted by centrifugation at $120000 \times g$ (Beckman, SW28 rotor) for $2 \mathrm{~h}$ at $4^{\circ} \mathrm{C}$. The resulting pellet was resuspended in $1 \mathrm{ml}$ of $1 \mathrm{mM}$ Tris/ $\mathrm{HCl}$ (pH 9.0) and then layered onto a $30 \%$ sucrose cushion prepared in $1 \mathrm{mM}$ Tris/ $\mathrm{HCl}(\mathrm{pH} 9.0)$ and centrifuged at $160000 \times g$ (SW60 rotor, Optima L90K Beckman Coulter ultracentrifuge) for $60 \mathrm{~min}$ at $4^{\circ} \mathrm{C}$. The pellet was resuspended in sterile phosphate buffer and used for rabbit immunization.

Histopathological studies. For histopathological studies, 4 whole tadpoles were fixed in $10 \%$ neutral buffered formalin immediately after death and dehydrated through graded alcohols and xylol before being embedded in paraffin wax. Several $4 \mu \mathrm{m}$ thick sections were cut from each sample and stained with haematoxylin and eosin (H\&E). Skin, liver, kidney, gut, skeletal muscle and the nervous system were studied. Other internal organs could not be evaluated.

Immunohistochemical examination by means of the peroxidase anti-peroxidase (PAP) method was performed (Sternberger et al. 1970). The sections were incubated with specific rabbit antiserum raised against the purified virions of the ranavirus isolate, diluted to 1 in 1000. To evaluate the importance of Aeromonas hydrophila isolated from dead tadpoles, tissue sections were stained using a rabbit antiserum against this bacterium, which was diluted to 1 in 1000 and had been prepared specifically for this purpose. Pre-immune rabbit sera were used as negative controls.

Preparation of antisera. To obtain a rabbit antiserum against the virus isolated from the CMT tadpoles, a New Zealand white rabbit was immunized with purified virions (175 $\mathrm{\mu g}$ of protein) emulsified with complete Freund's adjuvant at Days 1, 14, 21 and 28. The last boost containing $175 \mu \mathrm{g}$ of protein in the absence of Freund's adjuvant was administered intravenously at Day 35. The serum from the bleed on Day 38 and the pre-immune serum from the same rabbit were used for immunohistochemical studies. An Aeromonas hydrophila rabbit antiserum was prepared following a similar immunization protocol. One rabbit was intramuscularly inoculated at Days 1, 14, 21 and 28, with $0.5 \mathrm{ml}$ of $\sim 10^{8}$ live bacteria cultured from a single colony isolated from a sick and recently dead CMT tadpole. The pre-immune serum from the same rabbit was used as a negative control.

\section{RESULTS}

\section{Bacteriology}

Aeromonas hydrophila was isolated from all the tadpole samples analysed (from both the liver and the heart of the 2 larger animals and from the visceral tissues of the other 7), using both TSA and blood agar culture media. Identification was done using the API biochemical test strip system. For all the samples studied, A. hydrophila was the only bacteria present on the culture plates.

\section{Virology}

The inoculation of EPC cells with filtered tissue homogenates produced a CPE that was not observed in mock-infected cells. The observed CPE was similar to that observed previously in iridovirus-infected cell cultures (Fraser et al. 1993, Jancovich et al. 1997, Tapiovaara et al. 1998), leading us to suspect that the causative agent was an iridovirus.

\section{Virus identification}

To determine the identity of the causative agent, DNA was extracted from cultured cells exhibiting $\mathrm{CPE}$ and then PCR-amplified using primers specific for highly conserved regions within 2 key viral genes: 
the DNA polymerase gene of large DNA viruses (Hanson et al. 2006) and the MCP gene of FV3 and other iridoviruses (Mao et al. 1997). Respective DNA fragments of $\sim 660$ and $500 \mathrm{bp}$ were amplified and sequenced. The resulting nucleotide sequence data were used to perform similarity searches against sequences in the GenBank data base. At the amino acid level, the predicted sequence of the CMTV DNA polymerase showed a high level of identity to other ranavirus DNA polymerase sequences. The highest BLAST scores were against the DNA polymerases of TFV (99\% identity), ATV (99\%), Regina ranavirus (RRV) (99\%) and FV3 (98\%). Significant identity was also found with the DNA polymerase genes of other more divergent ranaviruses such as the largemouth bass ranavirus (LMBV), grouper iridovirus (GIV) and
Singapore grouper iridovirus (SGIV) (BLAST scores of 76, 69 and $69 \%$ respectively). Lower levels of identity were found with lymphocystis disease virus (LCDV) (44\%), which is a member of the genus Lymphocystivirus (Fig. 1). These results were confirmed by analysis of a second gene, the MCP gene. The predicted amino acid sequence of the CMTV MCP PCR fragment showed a high level of identity to several iridovirus MCP sequences. It was 98, 97, 97, 96, $95,81,76,76$ and $48 \%$ identical to the partial MCP sequence obtained from EHNV, FV3, TFV, ATV, RRV, LMBV, GIV, SGIV and LCDV respectively (Fig. 2). The corresponding DNA polymerase sequence for EHNV is not available in the data bases, hence it has not been included in the alignments shown in Fig. 1 or in Fig. 3A.

\begin{tabular}{|c|c|c|}
\hline & \multicolumn{2}{|c|}{ VCYSTRVDPGTPGSETFEWEDHLNCVHDPRKVEYERL } \\
\hline FV & \multirow{2}{*}{\multicolumn{2}{|c|}{$\begin{array}{l}\text { VCYSTRVDPGTPGSETFEWEDHLNCVHDPRKVEYERL } \\
\text { VCYSTRVDPGTPGSETFEWEDHLNCVHDPRKVEYERL }\end{array}$}} \\
\hline IV & & \\
\hline eV & \multicolumn{2}{|l|}{ VCYSTRVDPGTPGSETFEWEDHLNCVHDPRKVEYE] } \\
\hline 3 & \multicolumn{2}{|l|}{ JCYSTRVDPGTPGSETFTWEDHLNCVHDPRKVEYEF } \\
\hline IBV & \multicolumn{2}{|l|}{ VCYSTRVEPGTPGSETFEWEDHLNCCHDPRKIEYE } \\
\hline IV & \multicolumn{2}{|c|}{ ICYSTQADLNDPTAETFEWEDHLNCPHDHRKQEYDRL } \\
\hline GIV & \multirow{2}{*}{\multicolumn{2}{|c|}{ ICYSTQADLNDPTAEIFEWEDHLNCPHDHRKQEYDRL }} \\
\hline CDV & & \\
\hline [TT & \multicolumn{2}{|l|}{ PRKRVDDRRLVVDTLNTVLDAQRMLRTTRATLKNQ } \\
\hline EV & \multicolumn{2}{|l|}{ PRKRVDDRRLVVDTLNTVLDAQRMLRTTRAALKNQL } \\
\hline $\mathrm{TV}$ & \multicolumn{2}{|l|}{ PRKRVDDRRLVVDTLNMVLDAQRMLRTTRATLKNQL } \\
\hline RV & \multicolumn{2}{|l|}{ PRKRVDDRRLVVDTLNMVLDAQRMLRTTRATLKNQI } \\
\hline v3 & \multicolumn{2}{|l|}{ PRKRVDDRRLVVDTLNTVLDAQRMLRTTRAALKNQ } \\
\hline MBV & \multicolumn{2}{|c|}{ SRKRAQERQLVVDSLNTVMAAQ̈KMLRNTRADLKNQ̃L } \\
\hline IV & \multirow{2}{*}{\multicolumn{2}{|c|}{$\begin{array}{l}\text { SRKNAADDRQTVQDTLNAVLSAQKKLLRTTRAAIKNS̃LC } \\
\text { SRKNAAGROTVODTLNAVLSAOKLLRTTRAAIKNSL }\end{array}$}} \\
\hline GIV & & \\
\hline & \multicolumn{2}{|l|}{ KTQDDRILI - - - SRCEDKVK } \\
\hline ITV & \multicolumn{2}{|c|}{ MPTILTDLLDGRKRAKKAKAEAKDSITKITMDKRQLZ } \\
\hline $\mathrm{PV}$ & \multirow{2}{*}{\multicolumn{2}{|c|}{$\begin{array}{l}\text { MPTILTDLLDGRKRAKKAKAEAKDSITKITMDKRQL } \\
\text { MPTILTDLLDGRKRAKKAKAEAKDSITKITMDKRQL }\end{array}$}} \\
\hline $\mathrm{TV}$ & & \\
\hline$R V$ & \multicolumn{2}{|l|}{ MPTILTDLLDGRKRAKKAKAEAKDSITKITMDKRQI } \\
\hline FV3 & \multicolumn{2}{|l|}{ MPTILTDLLDGRKRAKKAKAEAKDSITKITMDKRQL } \\
\hline LMBV & \multicolumn{2}{|l|}{ MPTILTNLLDSRKRAKAAKAAATDKITAITMDKRQ̄] } \\
\hline 1 & \multicolumn{2}{|l|}{ MPTILTNLLEGRAKAKKAKTAAKDPITRITMDKRQ } \\
\hline GI & \multicolumn{2}{|l|}{ MPTILTNLLEGRARAKKAKTAAKDPITRITMDKRQ̃ } \\
\hline 枚 & \multicolumn{2}{|l|}{ VPAIVANLLDYRKRVKAQKVTTTNQTLKIVLDKRQI } \\
\hline & & \\
\hline & GA & \\
\hline $\mathrm{TV}$ & TYFGRQCIEKAASI & \\
\hline RRV & 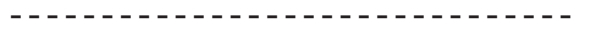 & \\
\hline V3 & & \\
\hline LMI & $Y Y \perp G K Q C \perp F$ & \\
\hline GI & TYLGRQ̋CIETAATLI & \\
\hline$S G \perp V$ & EGAMTVTYLGRQCIETAATLIGSEHGGTL & \\
\hline$a r+2$ & & \\
\hline
\end{tabular}

Fig. 1. Multiple alignment of iridovirus DNA polymerase sequences. Deduced amino acid sequence of a 205 amino acid region of the DNA polymerase gene of the common midwife toad virus (CMTV) (EMBLBank: CAQ63494.1) shown on the first line was aligned with the corresponding region from other iridoviruses using the programs Clustal X (1.81) (Thompson et al. 1997) and Genedoc (Karreman 2002). GenBank accession numbers for sequences used in the alignment are: tiger frog virus (TFV) (AAL77804.1), Ambystoma tigrinum stebbensi virus (ATV) (AAP33223.1), Regina ranavirus (RRV) (AAK54493.1), frog virus 3 (FV3) (AAT09720.1), largemouth bass ranavirus (LMBV) (ABA41591.1), grouper iridovirus (GIV) (AAV91098.1), Singapore grouper iridovirus (SGIV) (AAS18143.1) and lymphocystis disease virus (LCDV) (ABP87969.1). Amino acid 1 in this figure corresponds to amino acid 491 in the full-length sequence of FV3 major capsid protein. Amino acids that differed from those in CMTV are shown by shading. Gaps in the LCDV sequence are indicated by a dash (-). Note that the complete DNA polymerase sequence of the aligned fragment is not available for RRV 


\begin{abstract}
CMTV NLERAMYGGSDATTYFVKEHYPVGWFTKLPSLAAKMSGNPAFGQQFSVGVPRSGDYILNA 60 EHNV NLERAMYGGSDATTYFVKEHYPVGWFTKLPSLAAKMSGNPAFGQQFSVGVPRSGDYILNA 60 TFV NLERAMYGGSDATTYFVKEHYPVGWFTKLPSLAAKMSGNPAFGQQFSVGVPRSGDYILNA 60 FV3 NLERAMYGGSDATTYFVKEHYPVGWFTKLPSLAAKMSGNPAFGQQFSVGVPRSGDYILNA 60 ATV NLERAIYGGSDATTYFVKEHYPVGWFTKLPSLAAKMSGNPAFGQQFSVGVPRSGDYIINA 60 RRV NLERAIYGGSDATTYFIKEHYPVGWFTKLPSLAAKLSGNPAFGQQFSVGVPRSGDYIINA 60 LMBV SLDKALYGGKDATTYFVKEHYPVGWFTKLPTAATKTSGTPAFGQHFSVGVPRSGDYVLNS 60 SGIV NLDRALYGGKDATTYFIKEHYPVGWFTKLPTMATRVSGNPAFGQEFSVGVPRSGDYVLNA 60 GIV NLDRALYGGKDATTYFIKEHYPVGWFTKLPTMATRVSGNPAFGQEFSVGVPRSGDYVLNA 60 LCDV -IEKHLYGGDSAVAYFVRETKKCTWFSKLPVLLTRCSGSPNFDQEFSVNVSRGGDYVLNS 59

CMTV WLVLKTPEVKLLAANQLGDNGTIRWTKNPMHNIVENVNLSFNDISAQSFNTAYLDAWSEY 120 EHNV WLVLKTPEVKLLAANQLGDNGTIRWTKNPMHNIVENVNLSFNDISAQSFNTAYLDAWSEY 120 TFV WLVLKTPEVELLAANQLGENGTIRWTKNPMHNIVESVTLSFNDISAQSFNTAYLDAWSEY 120 FV3 WLVLKTPEVELLAANQLGDNGTIRWTKNPMHNIVESVTLSFNDISAQSFNTAYLDAWSEY 120 ATV WLVLKTPEVKLLAANQLGENGTIRWTKNPMHNIVENVNLSFNDISAQSFNTAYLDAWSEY 120 RRV WLVLKTPEVKLLAANQLGENGTIRWTKNPMHNIVENVNLSFNDISAQSFNTAYLDAWSEY 120 LMBV WLVLKTPQIKLLAANQFNANGTIRWTKNLMHNVVEHAALSFNEIQAQQFNTAFLDAWNEY 120 SGIV WLTLKTPEIKLLETNRLGANGTVRWTKNLMHNAVEHASLTFNDICAQQFNTAYLDAWTQF 120 GIV WLTLKTPEIKLLDTNRLGANGTVRWTKNLMHNAVEHASLTFNDICAQQFNTAYLDAWTQF 120 LCDV WMTVRIPAIKLKADNRMNNNGTIRWCKNLFHNLIKQTSVQFNDLVAQKFESYFLDYWAAF 119
\end{abstract}

$\begin{array}{lll}\text { CMTV } & \text { TMPEAKRIGYYNMIGNTSDLINPAPATGQDGARVLPAKNLVLPLP } & 165 \\ \text { EHNV } & \text { TMPEAKRIGYYNMIGNTSDLINPAPATGQNGARVLPAKNLVLPLP } & 165 \\ \text { TFV } & \text { TMPEAKRIGYYNMIGNTSDLINPAPATGQDGARVLPAKNLVLPLP } & 165 \\ \text { FV3 } & \text { TMPEAKRTGYYNMIGNTSDLINPAPATGQDGARVLPAKNLVLPLP } & 165 \\ \text { ATV } & \text { TMPEAKRIGYYNMIGNTSDLINPAPATGQNEARVLPAKNLVLPLP } & 165 \\ \text { RRV } & \text { TMPEAKRIGYYNMIGNTSDLINPAPATGQNEARVLPANLVLP } & 165 \\ \text { LMBV } & \text { TMPEAKRIGYYNMIGNTSDLVNPAPATDQAGARVLPAKNLVLPLP } & 165 \\ \text { SGIV } & \text { NMCEGKRIGYDNMIGNTSDMTNPTPAQGQDGARTLPSKNLVLPLP } & 165 \\ \text { GIV } & \text { NMCEGKRIGYDNMIGNTSDMTNPTPAQGQDGARTLPSKNLVLPLP } & 165 \\ \text { LCDV } & \text { SMCGSKRAGYNNMIGNTIDMIQPVDHTG-----MLPEKVLVLPLP } & 159\end{array}$

Fig. 2. Multiple alignment of iridovirus major capsid protein (MCP) sequences. Deduced amino acid sequence of a 165 amino acid region of the MCP gene of the common midwife toad virus (CMTV) (EMBLBank: CAR82589.1) shown on the first line was aligned with the corresponding region from other iridoviruses using the programs Clustal X (1.81) (Thompson et al. 1997) and Genedoc (Karreman 2002). GenBank accession numbers for sequences used in the alignment are: epizootic haematopoietic necrosis virus (EHNV) (AAO32315.1), tiger frog virus (TFV) (AAL77814.1), Ambystoma tigrinum stebbensi virus (ATV) (AAP33191.1), Regina ranavirus (RRV) (AAC29485.1), frog virus 3 (FV3) (AAT09750.1), largemouth bass ranavirus (LMBV) (AAC29488.1), grouper iridovirus (GIV) (AAV91066.1), Singapore grouper iridovirus (SGIV) (AAS18087.1) and lymphocystis disease virus (LCDV) (AAC24486.2). Amino acid 1 in this figure corresponds to amino acid 21 in the full-length sequence of FV3 MCP (Mao et al. 1996). Amino acids that differed from those in CMTV are shown by shading. Gaps in the LCDV sequence are indicated by a dash (-)

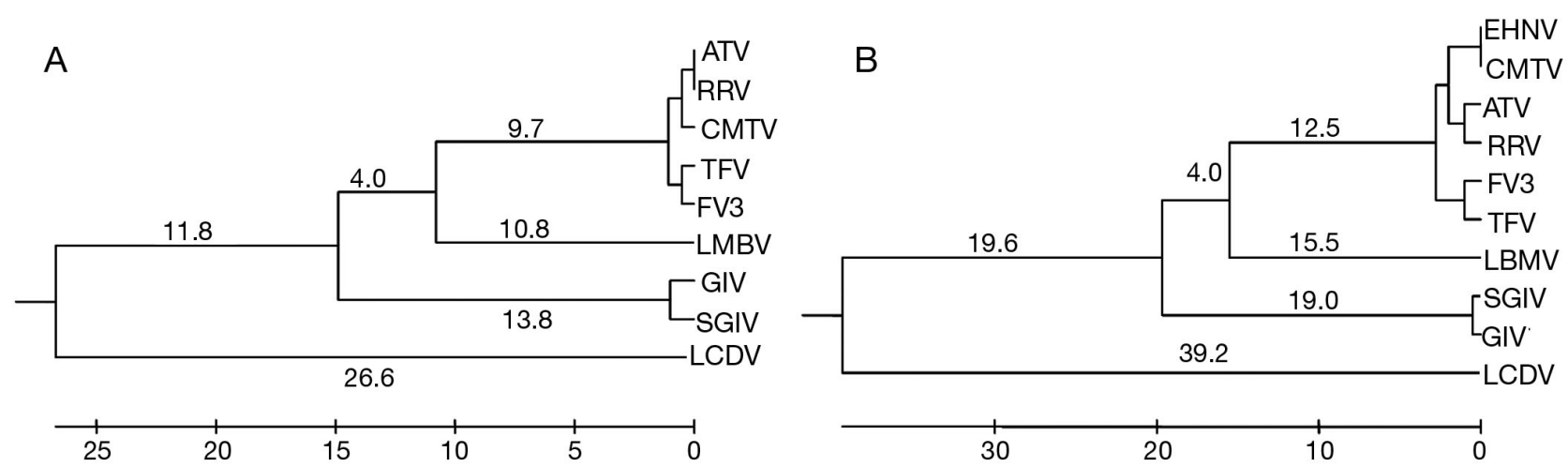

Fig. 3. Evolutionary relationships of the common midwife toad virus (CMTV) with representative iridoviruses. Phylogenetic and molecular evolutionary analyses of the iridovirus (A) DNA polymerases and (B) major capsid protein were conducted using MEGA version 4 (Tamura et al. 2007). Branch length, indicated by the scale beneath the tree, is proportional to the number of amino acid substitutions. See Fig. 1 for full virus names 
Phylogenetic analysis, based on the DNA polymerase (Fig. 3A) and MCP (Fig. 3B) BLAST results, showed that the virus isolated from the CMT tadpoles clusters more closely to EHNV, FV3, TFV, RRV and ATV than to LMBV, GIV and SGIV (more distantly related ranaviruses). As expected, LCDV which is a member of the genus Lymphocystivirus, is located on a different branch in the phylogenetic tree.

\section{Pathology and immunohistochemistry}

Systemic haemorrhages were observed macroscopically, mainly around the eyes and within the skin (Fig. 4), but also in the gills and internal organs.

Microscopic lesions were similar to those described for the systemic haemorrhagic form of ranavirus disease in frogs and other amphibians (Cunningham et al. 1996), consisting primarily of variably sized foci of necrosis throughout most organ systems. Round, intracytoplasmic, basophilic inclusions, consistent with ranaviral inclusions (Cunningham et al. 1996, 2008), were present in the skin, liver, kidney and gastrointestinal tract, accompanied by varying degrees of necrosis. Pyknotic cell nuclei containing condensed chromatin were observed. Histological lesions were not observed in the nervous system or in skeletal muscle. Immunolabelling for CMTV was observed within the skin, liver, kidney and gastrointestinal tract. Antigen labelling in the epidermis and dermis was focal (Fig. 5). Hepatocytes and hematopoietic tissue subjacent to the hepatic capsule frequently contained viral inclusions that were commonly associated with areas of necrosis (Fig. 6A). Immunolabelling, using the antiserum raised against the purified CMTV, was also observed in the liver (Fig. 6B). Inclusions and necrotic cells were observed in renal glomeruli (Fig. 7A) and intense immunolabelling for CMTV was present within these glomeruli (Fig. 7B). A low level of immuno-
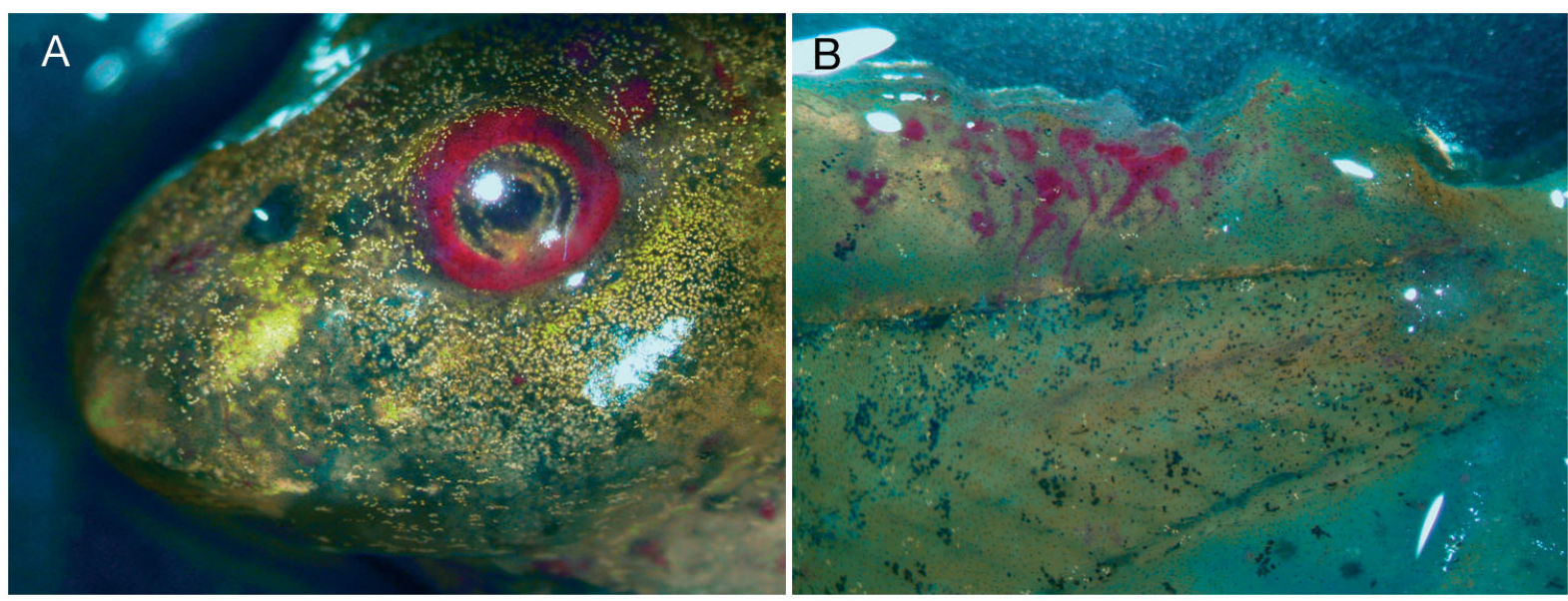

Fig. 4. Alytes obstetricans. Tadpole with haemorrhages (A) around the eye and (B) within the skin
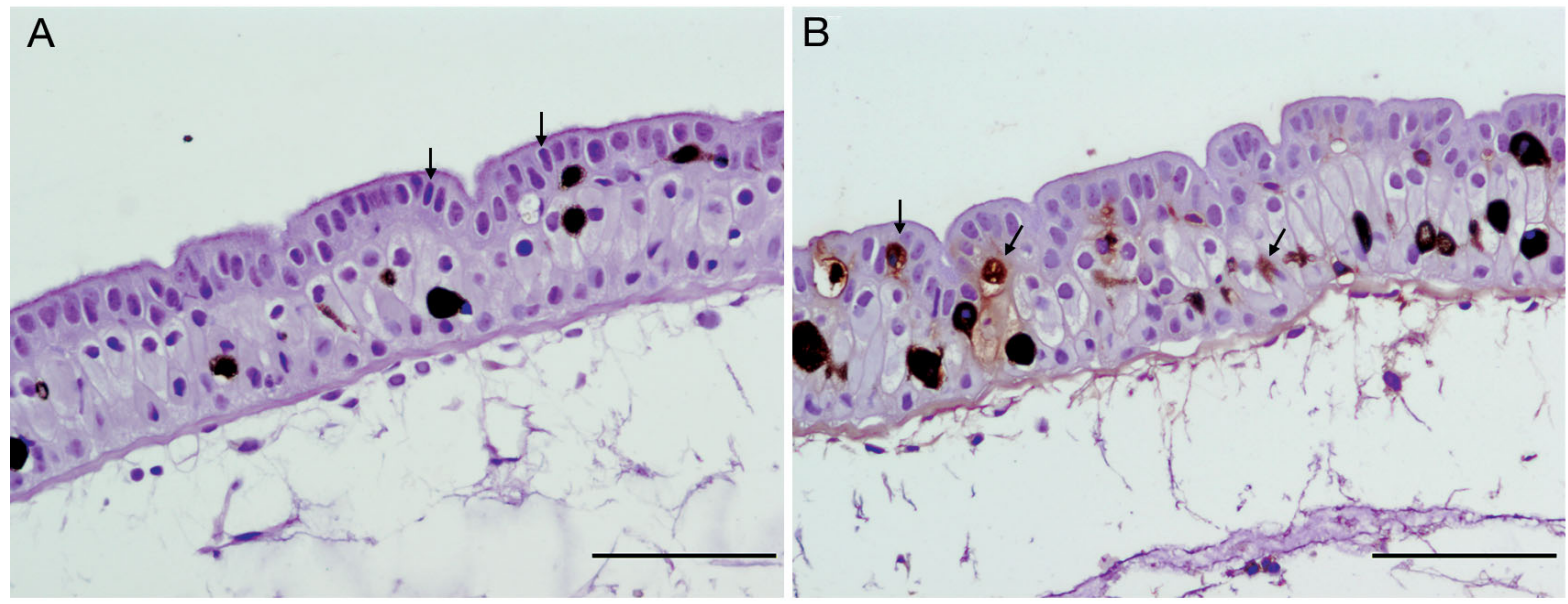

Fig. 5. Alytes obstetricans. Skin. (A) Cell nuclei showing condensed chromatin (arrows). Staining was done with haematoxylin and eosin. Scale bar $=100 \mu \mathrm{m}$. (B) Focal positive immunolabelling in the epidermis and dermis (arrows), using the peroxidase anti-peroxidase method. Scale bar $=100 \mu \mathrm{m}$ 

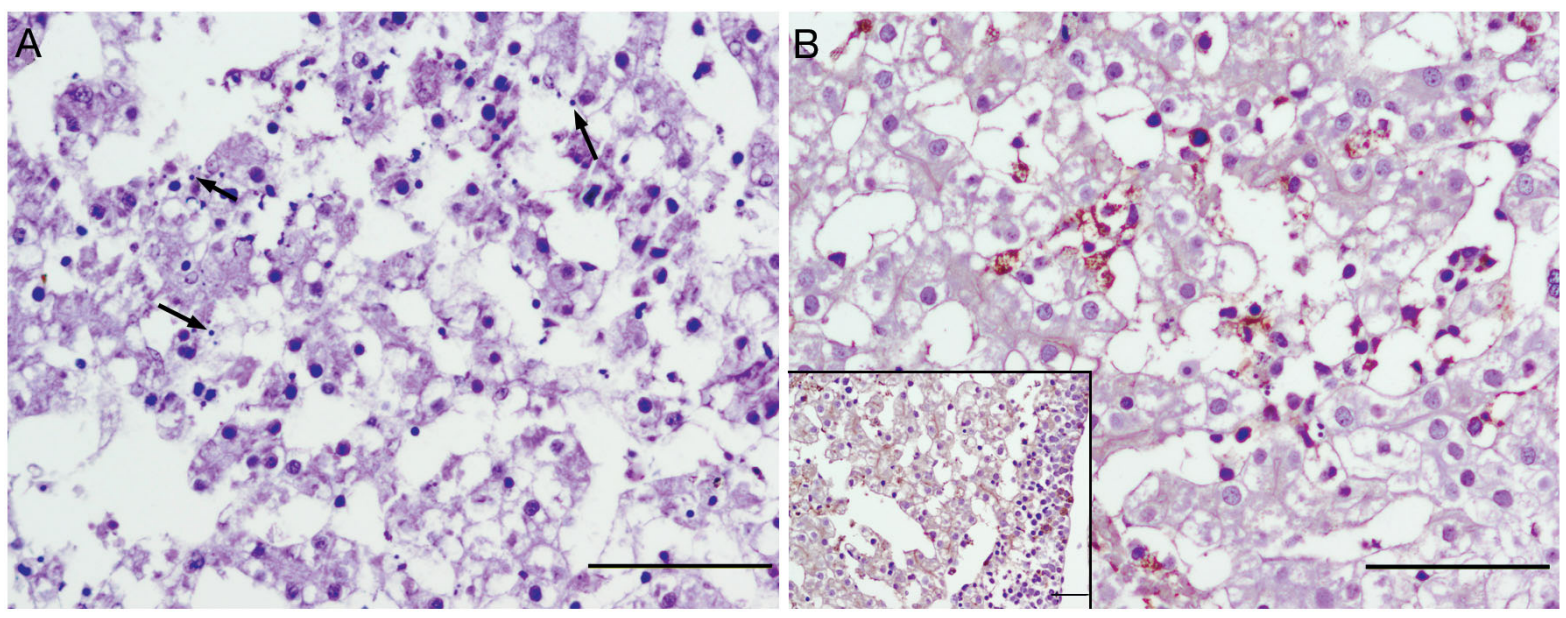

Fig. 6. Alytes obstetricans. Liver. (A) Areas of focal necrosis with hepatocytes containing viral inclusions (arrows). Staining was done with haematoxylin and eosin. Scale bar $=100 \mu \mathrm{m}$. (B) Hepatocytes showing positive immunolabelling for ranavirus, using the peroxidase anti-peroxidase method. Scale bar $=100 \mu \mathrm{m}$. Inset: Haematopoietic tissue subjacent to the hepatic capsule also shows intense immunolabelling. Scale bar $=50 \mu \mathrm{m}$

labelling was detected within tubule epithelial cells. The intestine was also immunolabelled for the virus, with some mucosal epithelial cells containing intracytoplasmic viral inclusions and pyknotic nuclei (Fig. 8A), and antigen being present within the mucosa (Fig. 8B). CMTV immunolabelling was occasionally seen within endothelial cells in the intestinal submucosa. The preimmune serum did not react in any of the tissues analysed (data not shown). Moreover, the rabbit antiCMTV did not react with the corresponding tissues taken from healthy CMT tadpoles, demonstrating the specificity of this antiserum.

Immunohistochemical studies carried out to investigate the presence of Aeromonas hydrophila demon- strated that this bacterium was only significantly present within the renal tubule epithelial cells. Bacterial antigen was not observed in the skin, liver, gastrointestinal tract, muscle or in the nervous system (data not shown).

\section{DISCUSSION}

This study is the first description of a ranavirus isolated from the CMT and the first isolation of this virus on the Iberian Peninsula. The diagnosis of ranavirus infection was based on a combination of clinical signs, gross and microscopic lesions, positive immuno-
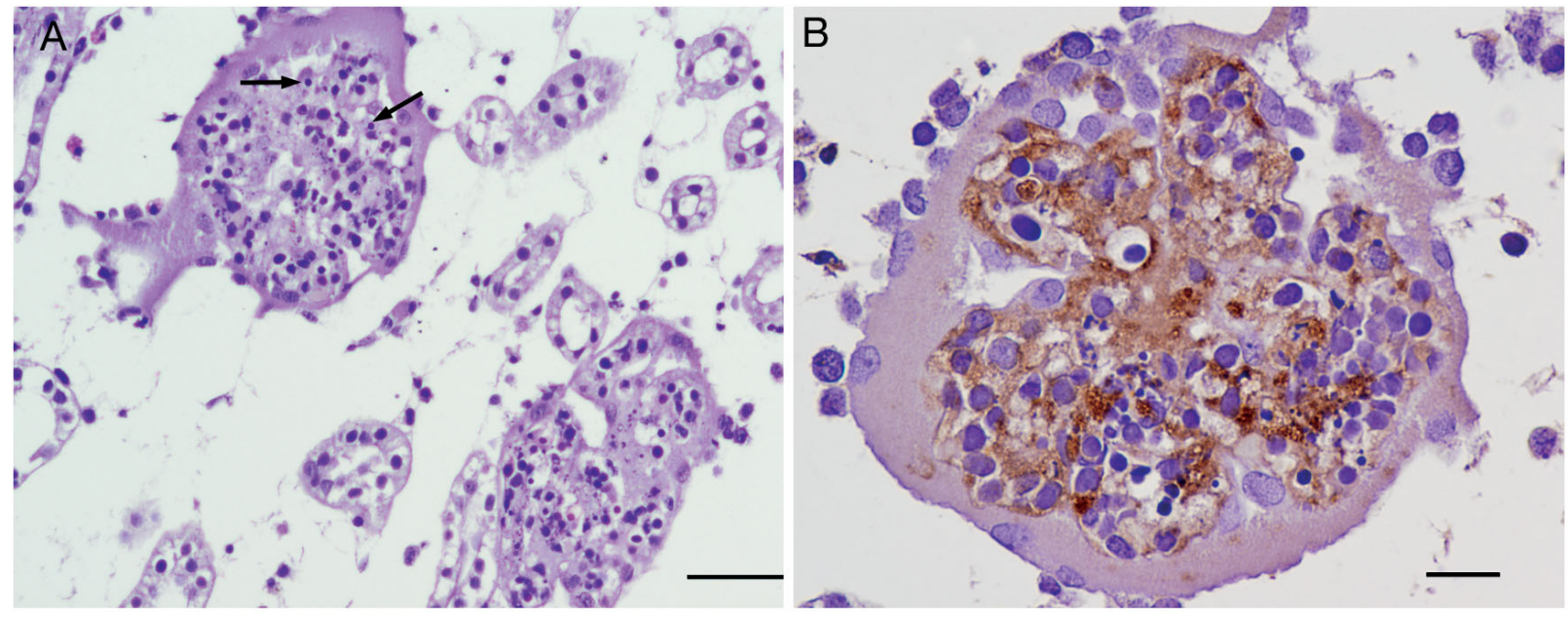

Fig. 7. Alytes obstetricans. Kidney. (A) Viral inclusions (arrows) and necrotic cells in renal glomeruli. Staining was done with haematoxylin and eosin. Scale bar $=50 \mu \mathrm{m}$. (B) Renal glomerulus positive for ranavirus antigen, using the peroxidase antiperoxidase method. Scale bar $=20 \mu \mathrm{m}$ 

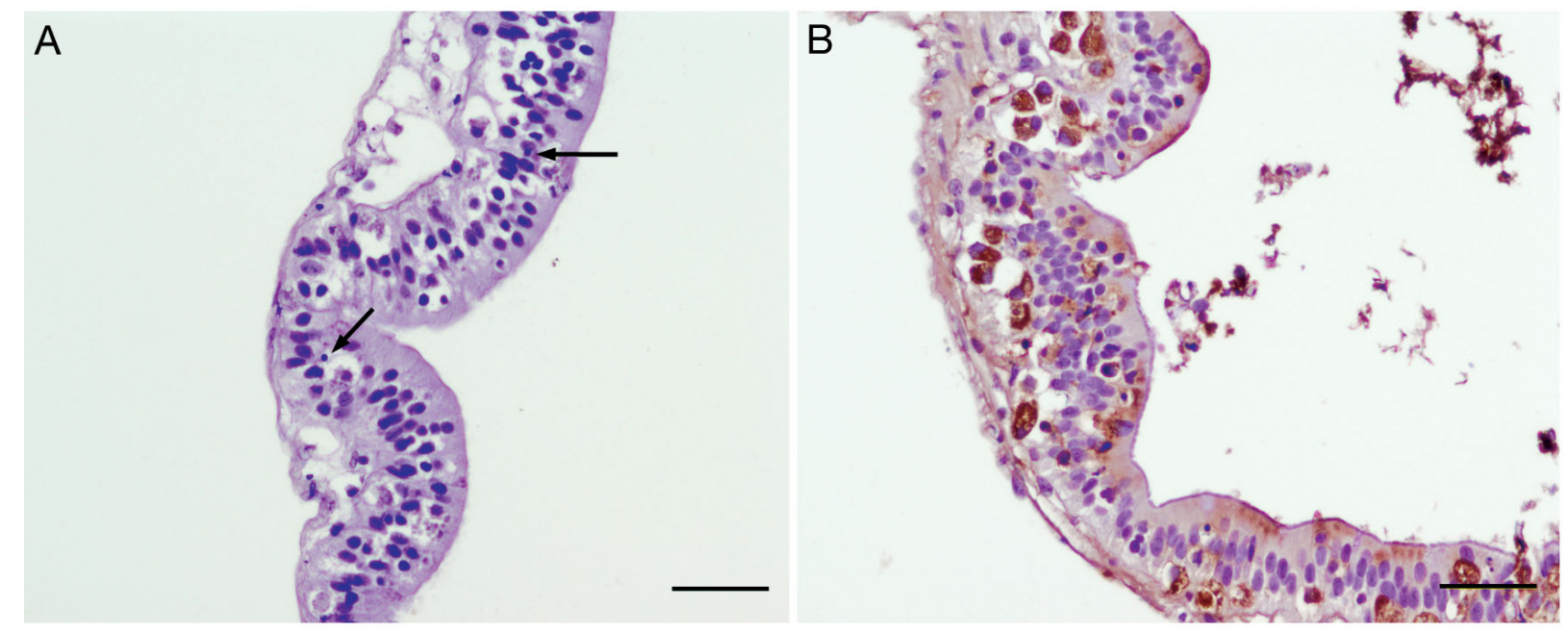

Fig. 8. Alytes obstetricans. Intestine. (A) Focal necrotic areas with cells containing intracytoplasmic viral inclusions (arrows). Staining was done with haematoxylin and eosin. Scale bar $=50 \mu \mathrm{m}$. (B) Intestine mucosa cells positive for virus antigen, using the peroxidase anti-peroxidase method. Note occasional immunolabelling in submucosa endothelial cells. Scale bar $=50 \mu \mathrm{m}$

labelling for ranavirus in different organs, and virus isolation and molecular characterisation. CMTV is pathogenic for CMT tadpoles. Ranaviruses usually cause an acute disease characterised by systemic haemorrhages (Daszak et al. 1999). Aeromonas hydrophila was also isolated from infected tadpoles; this bacterium is known to produce haemorrhagic septicaemia in animals such as snakes (Esterabadi et al. 1973). However, A. hydrophila is a commensal on the skin and gut of amphibians and recent studies revealed that its presence in iridovirus-infected animals is either secondary or postmortem (Cunningham et al. 1996, 2007). In addition, this bacterium is frequently isolated from aquatic species, with or without disease (Bollinger et al. 1999). Taking into account the virus isolation, the immunohistochemical results and the ranavirus distribution in tadpoles, it was concluded that $A$. hydrophila was not significant to disease development, and could thus be considered a secondary agent or postmortem invader, as has been previously observed in frogs with ranavirus disease (Drury et al. 1995, Cunningham et al. 1996, 2007).

The CPE we observed in EPC monolayers infected with filtrates of visceral tissue homogenates taken from diseased tadpoles and with passaged virus was consistent with that caused by iridoviruses isolated previously from fish and amphibians (Fraser et al. 1993, Cunningham et al. 1996, Jancovich et al. 1997, Tapiovaara et al. 1998). We therefore used purified virions in raising an antiserum against this virus to facilitate our studies and obtain DNA sequence data to investigate the identity of this virus.

To distinguish among closely related ranavirus isolates, sequence analysis of one or more viral genes is re- quired. Iridoviruses are characterised as having highly conserved regions within genes such as the MCP (Mao et al. 1996, 1997, Tidona et al. 1998, Hyatt et al. 2000) and DNA polymerase genes (Hanson et al. 2006). To investigate the phylogeny of CMTV, phylogenetic and molecular evolutionary analyses of a region of the DNA polymerase and the MCP of CMTV were carried out. Our results showed that CMTV was closely related to other members of the Ranavirus genus such as EHNV, TFV, FV3, RRV and ATV, showing identities $>95 \%$ in both proteins. Ward (1993) states that identities $>80 \%$ indicate that we might be dealing with strains of the same viral species. However, knowing the level of identity that CMTV shares with other ranaviruses is not enough to establish whether CMTV is a novel ranavirus, a distinct isolate, or just a strain of e.g. EHNV (CMTV clusters very closely to EHNV in the MCP phylogeny tree); thus, more experiments such as restriction fragment length polymorphism (RFLP) and virus protein profile analysis are required to definitively classify CMTV. For example, Rana catesbeiana virus Z (RCV-Z) has been established as a novel pathogenic ranavirus (Majji et al. 2006). Although it shows high levels of identity in the MCP sequence with other ranaviruses (100\% with Rana grylio virus (RGV 9808) and EHNV, $98 \%$ with ATV and $97 \%$ with FV3), the virus protein profile and RFLP patterns are markedly different from those of FV3. It is our intention to do this kind of analysis in the future. To our knowledge, this is the first time that a ranavirus has been isolated from the CMT and this is the first description of a ranavirus on the Iberian Peninsula.

The macroscopic and microscopic lesions and the pattern of immunostaining described in this paper are 
consistent with those reported in other amphibians with ranavirus disease (Cunningham et al. 1996, 2008, Bollinger et al. 1999, Docherty et al. 2003). However, encephalitis, meningitis and necrosis of neuroepithelial tissue associated with viral inclusions, which were previously described in salamanders (Docherty et al. 2003), were not found in infected CMT tadpoles. Moreover, ulcerative skin syndrome, recently described by Cunningham et al. $(1996,2007)$ in metamorphosed frogs, was not observed in these animals.

Immunohistochemistry using rabbit CMTV antiserum showed a widespread distribution of the virus in tissues and confirmed the use of this polyclonal antibody as a useful tool for detecting ranavirus infection in animal tissue. We propose that immunohistochemistry is a useful complementary method to histopathology when investigating ranavirus infections. The positive immunohistochemical reaction to the ranavirus isolated from the tadpoles, and the location and histological features of the lesions, indicate that the disease and mortality outbreak was caused by ranavirus infection.

The mechanism of CMTV emergence in the CMT is unknown. This is the first time that a ranavirus infection has been reported in Spain; mortalities in neighbouring waterholes (the closest being $\sim 1 \mathrm{~km}$ away) were not observed and there have been no reports of ranavirus infection in the CMT elsewhere in its range. Amphibian ranaviruses can survive long periods at the bottom of ponds, particularly during winter (Jancovich et al. 1997); however, it is likely that disease outbreaks at the Picos de Europa National Park in previous years would have been detected since the Veterinary Services of the National Park carry out periodic inspections. Duffus et al. (2008) examined the mode of transmission of a FV3-like virus in aquatic amphibian communities. Their study postulates that transmission of the virus occurs between anuran and urodele species, with ambystomatid salamanders being the most likely reservoir for the ranavirus. It is possible that virus movement between ponds is mediated by salamanders or other amphibians living in these pond communities, as suggested by Brunner et al. (2004). In resistant species such as Xenopus laevis, FV3 can also become quiescent, making these species potential viral reservoirs (Robert et al. 2007). In the Picos de Europa, only one larva of the newt showing haemorrhages was observed, but no studies were done with this larva because it was too decomposed for useful examination. Ranavirus transmission could occur between newts and toads but there is not enough evidence on which to draw any conclusion in this respect; further studies are required to establish a mode of transmission for this virus. The unregulated commercial bait trade of amphibians, as has been observed with tiger salamander in the US, may also be a source of pathogen pollution and ranaviral disease spread (Picco \& Collins 2008). However, the outbreak in the Picos de Europa occurred in a water trough where fishing is not possible. Birds have the potential to mechanically transfer virus on their feathers, feet, bills, or by the regurgitation of ingested infected material (Whittington et al. 1996); thus, it is possible that the virus was recently naturally introduced from another region. We consider such a mode of spread as possible, although further studies are required to test this hypothesis.

Ranaviruses are known as important pathogens of fish and amphibians elsewhere (Daszak et al. 1999). Recently, ranavirus disease has emerged as a major cause of amphibian mortality in Britain (Cunningham et al. 2007), apparently due to human-mediated introduction from the USA (Hyatt et al. 2000). Human activity could cause the introduction of amphibian pathogens through fomites or other sources of infectious particles (St-Amour et al. 2008). It is possible that the emergence of ranavirus disease on the Iberian Peninsula is also human-mediated. It is important to remain vigilant in the Picos de Europa National Park and elsewhere in Spain in order to detect new outbreaks of ranavirus disease, and monitor the possible spread of this pathogen and its possible impact on wildlife biodiversity.

Acknowledgements. The authors thank the Veterinary Services of the Picos de Europa National Park for bringing the samples to the laboratory, P. Solano for helping with the processing of samples, and the Danish Veterinary Institute for providing the cell line. R.C. is a recipient of a Ramón y Cajal contract from the Spanish Ministerio de Educación y Ciencia cofinanced by Fondo Social Europeo.

\section{LITERATURE CITED}

Altschul SF, Madden TL, Schäffer AA, Zhang J, Zhang Z, Miller W, Lipman DJ (1997) Gapped BLAST and PSIBLAST: a new generation of protein database search programs. Nucleic Acids Res 25:3389-3402

Bollinger TK, Mao J, Schock D, Brigham RM, Chinchar VG (1999) Pathology, isolation and preliminary molecular characterization of a novel iridovirus from tiger salamanders in Saskatchewan. J Wildl Dis 35:413-429

> Brunner JL, Schock DM, Davidson EW, Collins JP (2004) Intraspecific reservoirs: complex life history and the persistence of a lethal ranavirus. Ecology 85:560-566

Chinchar VG, Essbauer S, He JG, Hyatt A, Miyazaki T, Seligy V, Willims T (2005) Iridoviridae. In: Fauquet CM, Mayo MA, Manilof J, Desselberger U, Ball LA (eds) Virus taxonomy: 8th report of the International Committee on the Taxonomy of Viruses. Elsevier, London, p 163-175

Cunningham AA, Langton TES, Bennett PMB, Lewin JF, Drury SEN, Gough RE, Macgregor SK (1996) Pathological and microbiological findings from incidents of unusual mortality of the common frog (Rana temporaria). Philos Trans R Soc Lond B 351:1539-1557 
Cunningham AA, Hyatt AD, Russell P, Bennett PM (2007) Emerging epidemic diseases of frogs in Britain are dependent on the source of Ranavirus agent and the route of exposure. Epidemiol Infect 135:1200-1212

Cunningham AA, Tems CA, Russell PH (2008) Immunohistochemical demonstration of Ranavirus antigen in the tissues of infected frogs (Rana temporaria) with systemic haemorrhagic or cutaneous ulcerative disease. J Comp Pathol 138:3-11

Daszak P, Berger L, Cunningham AA, Hyatt AD, Earl Green D, Speare R (1999) Emerging infectious diseases and amphibian population declines. Emerg Infect Dis 5: 735-748

$>$ Docherty DE, Meteyer CU, Wang J, Mao J, Case ST, Chinchar VG (2003) Diagnostic and molecular evaluation of three iridovirus-associated salamander mortality events. J Wildl Dis 39:556-566

Drury SEN, Gough RE, Cunningham AA (1995) Isolation of an iridovirus-like agent from common frogs (Rana temporaria). Vet Rec 137:72-73

Duffus AL, Pauli BD, Wozney K, Brunetti CR, Berrill M (2008) Frog virus 3-like infections in aquatic amphibian communities. J Wildl Dis 44:109-120

> Esterabadi AH, Entessar F, Khan MA (1973) Isolation and identification of Aeromonas hydrophila from an outbreak of haemorrhagic septicaemia in snakes. Can J Comp Med $37: 418-420$

Fijan N, Matasin Z, Petrinec Z, Valpotic I, Zwillenberg LG (1983) Some properties of the epithelioma papulosum cyprini (EPC) cell line from carp Cyprinus carpio. Ann Virol 134:207-220

Fijan N, Matasin Z, Petrinec Z, Valpotic I, Zwillenberg LO (1991) Isolation of an iridovirus-like agent from the green frog (Rana esculenta L.). Vet Arch 61: 151-158

Fraser WA, Keefe TJ, Bolon B (1993) Isolation of an iridovirus from farm-raised gouramis (Trichogaster trichopterus) with fatal disease. J Vet Diagn Invest 5:250-253

Hanson LA, Rudis MR, Vasquez-Lee M, Montgomery RD (2006) A broadly applicable method to characterize large DNA viruses and adenoviruses based on the DNA polymerase gene. J Virol 11:3-28

> Hyatt AD, Gould AR, Zupanovic Z, Cunningham AA, Hansberger SG, Whittington RJ, Coupar BEH (2000) Characterisation of piscine and amphibian iridoviruses. Arch Virol 145:301-331

Hyatt $\mathrm{AD}$, Williamson M, Coupar BEH, Middleton D and others (2002) First identification of a ranavirus from green pythons (Chondropython viridis). J Wildl Dis 38:239-252

> Jancovich JK, Davidson EW, Morado JF, Jacobs BL, Collins JP (1997) Isolation of lethal virus from the endangered tiger salamander Ambystoma tigrinum stebbinsi. Dis Aquat Org 31:161-167

Karreman C (2002) AiO, combining DNA/protein programs and oligo-management. Bioinformatics 18:884-885

Langdon JS, Humphrey JD, Williams LM, Hyatt AD, Westbury HA (1986) First virus isolation from Australian fish: an iridovirus-like pathogen from redfin perch, Perca fluviatilis L. J Fish Dis 9:263-268

Editorial responsibility: Alex Hyatt, Geelong, Victoria, Australia
Majji S, LaPatra S, Long SM, Sample R, Bryan L, Sinning A, Chinchar VG (2006) Rana catesbeiana virus Z (RCVZ): a novel pathogenic ranavirus. Dis Aquat Org 73: $1-11$

> Mao J, Tham TN, Gentry GA, Aubertin AM, Chinchar VG (1996) Cloning, sequence analysis, and expression of the major capsid protein of the iridovirus frog virus 3. Virology 216:431-436

> Mao J, Hedrick RP, Chinchar VG (1997) Molecular characterization, sequence analysis, and taxonomic position of newly isolated fish iridoviruses. Virology 229:212-220

- Picco AM, Collins JP (2008) Amphibian commerce as a likely source of pathogen pollution. Conserv Biol

> Robert J, Abramowitz L, Gantress J, Morales HD (2007) Xenopus laevis: a possible vector of Ranavirus infection? J Wildl Dis 43:645-652

Speare R, Smith JR (1992) An iridovirus-like agent isolated from the ornate burrowing frog Lymnodynastes ornatus in northern Australia. Dis Aquat Org 14:51-57

St-Amour V, Wong WM, Garner TWJ, Lesbarrères D (2008) Anthropogenic influence on prevalence of 2 amphibian pathogens. Emerg Infect Dis 14:1175-1176

Sternberger LA, Hardy PH, Cuculis JJ, Meyer HG (1970) The unlabeled antibody enzyme method of immunohistochemistry: preparation and properties of soluble antigen antibody complex (horseradish peroxidase-antihorseradish peroxidase) and its use in identification of spirochetes. J Histochem Cytochem 18:315-333

Tamura K, Dudley J, Nei M, Kumar S (2007) MEGA4: Molecular Evolutionary Genetics Analysis (MEGA) software version 4.0. Mol Biol Evol 24:1596-1599

> Tapiovaara H, Olesen NJ, Lindén J, Rimaila-Pärnänen E, von Bonsdorff $\mathrm{CH}$ (1998) Isolation of an iridovirus from pike-perch Stizostedion lucioperca. Dis Aquat Org 32: 185-193

> Thompson JD, Gibson TJ, Plewniak F, Jeanmougin F, Higgins DG (1997) The Clustal X windows interface: flexible strategies for multiple sequence alignment aided by quality analysis tools. Nucleic Acids Res 25:4876-4882

Tidona CA, Schnitzler P, Kehm R, Darai G (1998) Is the major capsid protein of iridoviruses a suitable target for the study of viral evolution? Virus Genes 16:59-66

Van Regenmortel MHV, Fauquet CM, Bishop DHL, Carsten EB and others (2000) Family Iridoviridae. In: Van Regenmortel MHV, Fauquet CM, Bishop DHL, Carsten EB and others (eds) Virus taxonomy: 7th report of the International Committee on the Taxonomy of Viruses. Academic Press, San Diego, CA, p 167-182

Ward CW (1993) Progress towards a higher taxonomy of viruses. Res Virol 144:419-453

Weng SP, He JG, Wang LL, Deng M and Chan SM (2002) Outbreaks of an iridovirus in cultured tiger frog, Rana tigrina rugulosa, in southern China. J Fish Dis 25:423-427

Whittington RJ, Kearns C, Hyatt AD, Hengstberger S, Rutzou T (1996) Spread of epizootic haematopoietic necrosis virus (EHNV) in redfin perch (Perca fluviatilis) in southern Australia. Aust Vet J 73:112-114

Submitted: June 20, 2008; Accepted: January 19, 2009

Proofs received from author(s): March 17, 2009 